and developing the work so admirably built up by Sir Percival Hartley. The international appreciation which his efforts have met with is shown by his election as chairman of the Expert Committee on Biological Standardization of the World Health Organization. Dr. Miles has not allowed his official duties to diminish his enthusiasm for investigation. He has been throughout, and he continues to be, an active research worker, being best known for his immunological studies of Brucella and, more recently, for his investigation of factors affecting the spread of infection within the animal body. In him the Lister Institute acquires a director of wide knowledge and experience, under whose energetic leadership research work will have every encouragement.

\section{Bacteriology in Leeds :}

Prof. J. W. McLeod, O.B.E., F.R.S.

JAMES WAITER McLEOD, who is retiring from the Brotherton chair of bacteriology in the University of Leeds, has profoundly influenced the development of his subject during the past thirty years. Born in January 1887, he received his early education at George Watson's College, Edinburgh, in Lausanne, and at Mill Hill School, and entered the University of Glasgow in 1903, graduating M.B., Ch.B. in 1908. He showed early that his interests lay in laboratory medicine, and, after a year of clinical training in the wards of John Cowan and Sir Kennedy Dalziel, he commenced research in bacteriology with Sir Robert Muir, and was appointed lecturer in pathology at Charing Cross Hospital, London, in 1909; during the First World War he served with distinction-mentioned in dispatches four times and awarded the O.B.E.- in the R.A.M.C. as officer commanding a mobile laboratory. On demobilization McLeod was appointed lecturer in bacteriology at the University of Leeds and became the first incumbent of the Brotherton chair in 1922 . During thirty years his contributions to the subject of bacteriology have been notable for their quality and diversity : the pathogenicity of streptococci, the problems of bacterial nutrition and respiration, study of the anaerobes, of the gonococcus, of diphtheria (both as a problem of bacteriology and of epidemiology), have among many other subjects claimed his attention, and in no instance have his findings failed to stand the test of time. Combining the outlook of a general biologist with the exactitude of a physicist and the humanity of a physician, it was but natural that the most notable influence which his work has exerted has been to integrate the study of bacteriology as a subject per se with its application to medicine. 'The honours which he has so rightly deserved - fellowship of the Royal Society, honorary D.Sc. of the University of Dublin, presidency of the Society of General Microbiology-have been a source of very real pleasure to all who know him, and his friends wish him every happiness in his retirement.

Dr. C. L. Oakley

Dr. Cyril Lestie Oakley, who succeeds Prof. McLeod, was born in 1907 and graduated in medicine from University College, London, in 1930, taking a first-class honours B.Sc. in zoology at the same time; three years later he took his M.D. in pathology. After three years as Graham Scholar at the University College Hospital Medical School, he was appointed experimental pathologist at the Wellcome Research Laboratories, Beckenham, in 1934, becoming head of the Immunology and Experimental Pathology
Department in 1947. He was elected a Fellow of University College, London, in 1950. During the Second World War he was responsible for the organization of a subsidiary unit of the Laboratories, at Carshalton, where part of the very large production of antitoxin and prophylacties for the Army was carried on. While a Graham Scholar, Dr. Oakley worked on the rate of regeneration of red cells after repeated bleedings. In his first years at Beckenham, besides being responsible for all the morbid histology work of the Laboratories, he worked on virus diseases, particularly influenza, setting up his own unit for making Elford membranes. He then became interested in the pathogenic Clostridia and, with his collaborator, Dr. G. H. Warrack, added greatly to the knowledge of the complex antigenic constitution of this group, discovering a number of new toxins and enzymes. He has of recent years, by the use of an ingenious method of immunization with two toxoids simultaneously, furthered very considerably our knowledge of the site of origin of antitoxin. One of the most remarkable observations in this work was the demonstration that aluminium hydroxide adsorbs tetanus or diphtheria toxoid when injected into omental or perirenal fat, and leads to a local production of antitoxin. Dr. Oakley has never abandoned his early zoological interest, and one of his hobbies has been a serious research into the anatomy and systematics of parasitic copepods.

\section{University of Aberdeen}

THE honorary degree of LL.D. of the University of Aberdeen has been conferred on the following, among others: Prof. Niels Bohr, professor of theoretical physics, University of Copenhagen ; Prof. H. Butterfield, professor of modern history in the University of Cambridge since 1944; Prof. James Ritchie, professor of natural history in the University of Edinburgh since 1936 ; Prof. H. E. Shortt, professor of medical protozoology in the University of London and head of the Department of Parasitology in the London School of Hygiene and Tropical Medicine; and Prof. David Landsborough Thomson, professor of biochemistry in McGill University, Montreal, since 1937.

\section{Medicine and the Mind}

For his Rede Lecture, given to the University of Cambridge this year and now published (pp. 30; Cambridge: At the University Press, 1952; $2 s .6 d$. net), Sir Russell Brain, president of the Royal College of Physicians, chose as his subject "The Contribution of Medicine to Oùr Idea of the Mind". Sir Russell pointed out that from an early stage of his training the medical practitioner is made aware of the intimate relationship between the body and the mind, that is, he is always dealing with a body-mind unity, though his chief concern may be with one or the other. The great advances in neurophysiology, neurology and psychiatry during the present century have given us a much more detailed knowledge, enabling us to correlate brain disturbance with mental changes. Disease has made a great contribution to our knowledge of the normal brain-mind relationship, and research has been facilitated by the use of the electro-encephalograph, a machine for amplifying and recording the minute electrical brain-rhythms. It is now known that certain people who behave abnormally have abnormal brain rhythms. Independently of the work of the neuro-physiologists and neuro-psychiatrists, a school of psychological thought 